\title{
NONLINEAR IMPACT OF CREDITS ON CURRENT ACCOUNT BALANCE: THE CASE OF TURKEY
}

\author{
DOI: 10.17261/Pressacademia.2020.1355 \\ PAP- V.12-2020(19)-p.79
}

Dincer Dedeoglu

Bahcesehir University, Department of Economics, Istanbul,Turkey.

dincer.dedeoglu@eas.bau.edu.tr, ORCID: 0000-0002-7308-9478

To cite this document

Dedeoglu, D., (2020). Nonlinear impact of credits on current account balance: the case of Turkey. PressAcademia Procedia (PAP), V.12, p.79 Permanent link to this document: http://doi.org/10.17261/Pressacademia.2020.1355

Copyright: Published by PressAcademia and limited licensed re-use rights only.

\section{ABSTRACT}

Purpose- The association between credit growth and current account balance become much stronger recently. A typical example of the interaction between credit expansion and current account deficit is the experience of Turkey in the 2010-2011 period after the QE policies of the advanced central banks. The demand channel may be the main reason behind the connection between the credits and the current account deficit in economies like Turkey. Undoubtedly changes in credit growth affect the current account, but inherently the impact of the positive changes in credits would not be similar to that of the negative changes. This paper aims to investigate the asymmetric relationship between the current account balance and credits in Turkey quarterly data from 1992 to 2019.

Methodology- The study employs the novel non-linear Autoregressive Distributed Lags model. In the analyses different model specifications along with different credit definitions are considered.

Findings- The analysis reveals that the positive innovations in credit growth affect current account deficit in a different way than the negative innovations in the long run. Further, it may be stated that the deteriorating impact of the increase in credit growth on current account balance is more than the improving impact of the decrease in credit growth on current account balance.

Conclusion- Based upon the findings it may be concluded that when assessing the external balance and designing appropriate monetary and macroprudential policies, asymmetric effects of credit developments on current account balance should be considered to avoid possible deteriorating impact of the credit expansion on the current account balance.

Keywords: Credits, Current account, cointegration, nonlinear ARDL, asymmetry

JEL Codes: C22; E44; F32

\section{REFERENCES}

Atoyan, R., Manning, J. and Rahman, J. (2013) Rebalancing: Evidence from Current Account Adjustment in Europe. 13/74.

Biggs, M., Mayer, T. and Pick, A. (2009) Credit and Economic Recovery. DNB Working Paper 218/2009. Amsterdam.

Borio, C. (2012) The Financial Cycle and Macroeconomics: What Have We Learnt, BIS Working Paper 395.

Dedeoglu, D. and Ogut, K.I. (2019) The Monetary Policy in Turkey After2008: The Case of a Small Open Economy. In Yurtseven, Ç.and Tekce, M.(Eds): Current Issuesin Turkish EconomyProblems and Policy Suggestions. Peter Lang: 63-98.

Ekinci, M.F., Erdem, P. and Kilinc, Z. (2015) “Credit Growth, Current Account and Financial Depth.” Applied Economics 47(17):1809-1821.

Ekinci, M.F. and Omay, T. (2019) Asymmetric Effects of Credit Growth on the Current Account Balance: Panel Data Evidence. Global Issues in Banking and Finance. In Ozatac N. and Gokmenoglu K.K. Springer: Cham, 11-25

Hiebert, P., Jaccard, I., and Schüler, Y. (2018) Contrasting Financial and Business Cycles: Stylized Facts and Candidate Explanations. Journal of Financial Stability 38((C)):72-80.

Kara, H. and Tiryaki, S.T. (2013) Credit Impulse and Busines Cycle. 2013/10. Ankara.

Mitra, S.K. (2014) Nonlinear Impact of Rain on Foodgrain Production in India. Applied Economics Letters, 21(14):1001-1005.

Phillips, S., Catão L., Ricci L., Bems, R., Das M., Di Giovann, J., Unsal D.F., Castillo M., Lee, J., Rodriguez J., and Vargas M. (2013) External Balance Assessment (EBA): Technical Background. IMF Working Paper 13/272.

Shin, Y., Byungchul, Y., and Greenwood-Nimmo, M. (2014) Modelling Asymmetric Cointegration and Dynamic Multipliers in a Nonlinear ARDL Framework. In Sickles, R. and Horrace, W. C.(Eds): Festschrift in Honor of Peter Schmidt, edited by. Springer: New York, 281-314 